\title{
Articles
}

\section{Thurman Arnold and the Theatre of the Law}

\section{Abe Fortas}

"[Lawyers] have an orchestra seat from which you observe the most fascinating spectacles. ... It is like watching a gorgeous ballet with a whole variety of dancers moving back and forth across the stage to create a scene of beauty and rhythm."

Thurman Arnold, Fair Fights and Foul 270-71.

I.

In this fashion, Thurman Arnold described the joy of practicing the art of the law. But he refused to take either himself or the law with entire seriousness. With tongue-in-cheek pomposity, he headed the chapter of his book in which the quoted words appear with this Arnoldism: "The Practice of Law is a Profession of Great Dignity the Pursuit of Which Requires Great Learning."1

As the passage quoted above reveals, Arnold enjoyed the role of an observer. But his was participant-observation, joyously responding to the pageant that he observed. Only an observer whose mind and heart and emotions vividly interact with the on-stage drama can really savor its pleasures. Arnold was such an observer. The human drama that he saw, the heroics and absurdities of life that he witnessed, the words that he read and heard: these were not merely data registered on the mind, but sparks which ignited his ideas and emotions, stimuli which adduced brilliant, pyrotechnic responses. His was not the mind which collects, assembles and redistributes. It transformed and enriched the data which he so voraciously sought and hungrily seized from the elaborate spread that life offered him.

It is therefore no wonder, as he tells us, that, in the varied experiences of his wide-ranging life, he most enjoyed his career as a teachera poor and inadequate word to describe his role in academia. He was indeed a teacher-a great teacher in the sense in which a tornado, sweeping away shabbiness and decay, may be an instrument of urban

1. T. ARNold, FaIr Fights AND Foul 252 (1965). 
renewal. Teaching for him was not just learning and organizing and communicating a segment of the law. The teaching chair that he occupied was an elevated post from which he could see life, bounce it about, reshape and deflate it, reduce it to its essential absurdity, inflate it to its potential greatness, toss it over to astonished colleagues and amazed students, and recapture and again bounce it about.

Arnold was an intellectual, but only if the term is lavishly defined. He was not an intellectual if the word describes only the accumulator of facts and information. He was, indeed, skeptical of facts. He was scornful of data presented as if they encapsulated life. To him, events were vast, dynamic and kinetic phenomena. They could not be grasped by capturing facts, even if that were possible. One might as well try to catch a river by extracting the objects in it. Events could be dealt with only by comprehension of their essence, and their essence could be communicated only by abstraction.

In the world of law and political theory, he anticipated the avant garde of the visual arts. His work dealt with life's realities, not by attempting to reproduce them representationally, but by boldly conceiving vast abstractions which often laid bare the essential reality which the fictions and formulae of the law had obscured.

He was intrepid, fearless and original in his wrestling matches with the raw material of life and the concepts of the law. He challenged ideas which time had sanctified. He challenged them not because he was irreverent, but because he was an essentially humble mnn. He did not believe that the truth could be captured by mortal man. He did not believe in eternal verities, even his own. He knew in his bones that life defies codification; that law can be no more than a tool for shaping life and coping with it for the time being; and that today's formula is tomorrow's curiosity.

He knew that life is a deep, tumultuous, disorderly stream, and that any man at any moment can see only the surface of a microscopic part of it, can grasp only a few drops of its immensity. He knew that to comprehend any of it, a man must immerse himself in its depths, feel its turbulence, and seek to understand the temper and direction of its vast currents.

He loved life because it was prolix, unlimited and turbulent. Conscious as he was of the limited effect of any man's efforts, he loved the process of coping with life-of trying to direct a bit of it, so that it served mankind and did not overwhelm the individual. And he loved the law because, in his hands, it was a wondrously flexible implement for that purpose. 
He was an artisan, a participant in life and the law. He had no taste for the simplicities of the static: Yes, no, this is so, that is not so, were words and phrases that, to Arnold, induced acute discomfort. His mind was too rich, too restless, too subtle, too complex for them.

So it was that in his brief career as an appellate judge, Arnold was not happy. He did not like the absolutes of pronouncing judgment, nor did he enjoy the process. An appellate judge deals with issues that are largely prefabricated, pre-processed by others. For Arnold, the four corners of a record-on-appeal, the limits set by the mind and ingenuity of others, were the walls of a prison. His genius was too rambunctious, his mind was too fertile-too eager to soar and dive-to be content within these limits.

So it was, that second to his experience in academia, Arnold loved the practice of the law. To it, he brought his unique qualities.

II.

In considering Arnold's career as a lawyer, it is necessary at the outset to admit that he did not observe Sir Edward Coke's prescription: "Give six hours to sleep; as many to the study of righteous laws; for four hours pray; devote two to meals; and what is over bestow upon the Sacred Muses." He would have been more enchanted by Sir Henry Hawkins' riposte: "If you spent all your time poring over the law, there would be none left for breaking it."2 There is also no evidence that he prayed four hours each day.

In July, 1945, after his resignation from the United States Court of Appeals for the District of Columbia Circuit, Arnold formed a partnership for the practice of law with a former associate in the Antitrust Division. The firm represented two extraordinary capitalists, Cyrus Eaton and Robert Young, in litigation to obtain control of the Pullman car service. They lost the case, ${ }^{3}$ and the partnership was soon dissolved. Thereafter, in January, 1946, the firm of Arnold and Fortas was organized.

The purpose of the firm was to provide a means for its two partners to make a living. Neither partner quite knew how this was to be done. At the outset, neither had a single client or any prospects; but both were dedicated to the great cause of economic survival which they had

2. Hine, Confessions of AN UNCOMMON ATtorney 3 (1945).

3. United States v. Pullman Co., 64 F. Supp. 108 (E.D. Pa. 1945), af'd mem, by an equally divided court, 330 U.S. 806 (1947). 
undertaken. Somehow, by the mysterious process of law and life, the venture went forward, and increasing numbers of partners and associates joined it.

The time was propitious for law practice in the Nation's capital. The Nation's business was struggling under the mass of rules, regulations and restrictions which World War II had spawned. New enterprises had arisen in great number. Washington know-how was in demand, and the proliferation of Washington law firms had not yet taken place. Lawyers who were veterans of the New Deal and government service were presumed to be qualified to find their way through the maze, to guide and assist companies which had unfamiliar problems.

These were relatively simple days in terms of the individual lawyer's approach to the problems of his working life. The object was to make a living, in economic terms. The criterion which determined the lawyer's decision as to whether he would represent a client, with few exceptions, was entirely pragmatic: Was the prospective client's problem such that the law firm could advise and represent the client with a reasonable prospect that the firm could contribute something of value for which payment could and would be received?

Criminal cases and controversies involving the poor and social issues did not come to the larger or established law firms. The poor and the ordinary persons accused of crime were generally unrepresented in those days, or their counsel were drawn from a specialized part of the bar or from "courthouse lawyers."

Occasionally a corporate lawryer might be appointed by the court to represent a defendant who could not otherwise obtain counsel, but such appointments were rare. Law firms of the Establishment would virtuously, and modestly, contribute to the inadequate and ineffective legal aid societies. And that was that.

There were, in the Nation, a few notable exceptions to this pattern, like the lawyers who undertook the defense of the Scottsboro defendants. But there was no suggestion that lawyers were not justified in conducting a purely commercial practice. A lawyer, young or old, came to his office to serve clients who enlisted, ordinarily by purchase, the services of his firm. If a lawyer had interests other than the commercial practice of his firm, such as serving the poor or oppressed, those interests were part of his personal life, not integrated with his work with the law firm.

It was largely by chance rather than by planned choice, that Arnold's firm first became involved in the service of non-commercial clients-in the issue of individual freedom from governmental oppression which 
arose in the middle 40's and 50's. As usual, of course, the chance that brought about the event was not mere accident. It was the product of time and place, and of the background and ideological identification of the members of the firm. We were "liberals." We were New Dealers.

The overwhelming issue of those years was the supposed Communist threat to the institutions of this Nation. The Depression and the New Deal had activated the social conscience of millions of our people. As usual, and as is currently happening, many of the young and not-so. young people of conscience sought ultimate and absolute answers to the startling problems of economic disarray, inadequacy of ideals, and corruption of practices which those events had disclosed. The ideology and agencies of Soviet Communism seemed to promise not just reform, but Utopia; and many of those who sought a final answer to social problems, along with some who searched for the warm comfort of togetherness in a seemingly noble venture, were irresistibly attracted to Communism's allure. Happily, there were vastly more flirtations than affaires, more engagements than marriages; the Communist apparatus, being essentially conspiratorial, would not accept many for membership, and the extreme rigidities and essential destructiveness of the Communists soon disillusioned all except a few of those who were first attracted to it.

But to the Establishment of those days, the danger of a Communist take-over was real and terrorizing; and the distinction between reformers and revolutionists was much too precarious for acceptance. The awesome power of the federal government was leveled upon them all, and a reign of terror ensued. The instruments were surveillance, accusa* tion, dismissal from government and private jobs, and public exposure as disloyalists. The hysteria reached its apogee in the mad behavior of Senator Joseph McCarthy. It subsided only as his excesses nauseated the American people and only after he was brought to heel by the formal censure of his Senatorial peers.

Arnold's firm became involved in 1946, in the early stages of the loyalty crusade. It entered the fray when one of its associates brought to the firm the problem of an acquaintance of his, a man named Friedman who was an official of the War Manpower Commission. Friedman had been discharged for disloyalty on the basis of alleged pro-Communist expressions and associations. We lost the case; ${ }^{4}$ but in the course of its defense the firm acquired the identification and commitment

4. Friedman v. Schwellenbach, 159 F.2d 22 (D.G. Cir. 1946), cert. denied, 890 US, 888 (1947), rehearing denied, 331 U.S. 865 (1947). 
which made inevitable its subsequent involvement in the resistance to McCarthyism.

In Fair Fights and Foul, Arnold quotes the following passage from the firm's brief in support of its petition for certiorari in the Friedman case: ${ }^{5}$

But this assault on freedom of opinion will not stop with Government employees. Assaults upon freedom have a habit of growing beyond a stated objective. They quickly attack not merely a manifestation, but freedom itself. So this crusade, once under way, will not stop with its victims in the federal service. It will spread and is now spreading over this country, blighting our democracy and bringing fear and distrust to American homes throughout the nation.

The prophecy proved all too true.

In the years that followed, extending into the 1960's, Arnold's firm was engaged in the defense or in attempts to obtain the reinstatement of many other government employees as well as in causes involving private citizens who were victims of the anti-Communist hysteria. Among them, to name only some of the matters of public record, were the cases involving Dorothy Bailey, ${ }^{\circ}$ Dr. John P. Peters of Yale, ${ }^{7}$ Owen Lattimore, $^{8}$ and Dr. Edward Condon, Director of the Bureau of Standards.

All of these cases involved the perennial and fundamental issues of First Amendment freedoms: the substantive right of individuals to differ from the orthodox; to hold and express dissenting opinions, however fundamentally divergent they may be; and to associate with others in the discussion and advancement of those views. Most of them involved fundamental questions of procedural rights: to specific charges, to confrontation and cross-examination, to judgments based solely on substantial evidence, to the presentation of a defense, and to counsel.

They were great social issues; but they were issues in the special province of the law and lawyers. When the same sorts of constitutional and legal issues were presented to Arnold by persons with whose political view he disagreed, he and his firm nevertheless readily enlisted in

5. Arnold, supra note 1 , at 205, quoting from Petitioner's Brief for Certiorari, Friedman v. Schwellenbach, cert. denied, 330 U.S. 838 (1947), rehearing denied, 331 U.S. 865 (1947).

6. Bailey v. Richardson, 182 F.2d 46 (D.C. Cir. 1950), af'd by an equally divided court, 341 U.S. 918 (1951).

7. Peters v. Hobby, 349 U.S. 331 (1954).

8. United States v. Lattimore, 232 F.2d 334 (D.C. Cir. 1955), aff'g 127 F. Supp. 405 (D.D.C. 1955); 215 F.2d 847 (D.C. Cir. 1954), modifying 112 F. Supp. 507 (D.D.C. 1953); 125 F. Supp 295 (D.D.C. 1954). 
their defense. Conspicuous among these cases was the litigation to free Ezra Pound from detention in the criminal ward at St. Elizabeth's Hospital, where he had been confined for thirteen years awaiting a certification of mental competence to stand trial for treason in World War II. ${ }^{9}$

As I reconsider these activities of Arnold and his law firm, $I \mathrm{am}$ impressed by certain respects in which they differ from the comparable activities of law firms today.

1. The costly, unremunerative and hazardous work of defending individuals whose First Amendment rights were at stake was not undertaken as part of any general acceptance by the profession of a duty to serve in these causes. There were, indeed, other lawyers and law firms which took the risk of public condemnation and shouldered the sub. stantial burden of the defense of loyalty cases, but there were not many. Paul Porter tells of this barbed exchange with a fellow lawyer whom he encountered at a golf club and who reflected the hostility of much of the bar to this work:

Lawyer: "Paul, I understand your firm is engaged in defending homosexuals and Communists."

Porter: "That's right. What can we do for you?"

Today, one of the welcome and encouraging developments in our Nation has been the widespread acceptance by the bar of an obligation to provide representation for the poor in both civil and criminal matters. To many young lawyers this acceptance of a duty to represent individuals is inadequate. They believe that the bar has and should recognize an obligation to represent, not merely individuals, but causes, such as product safety or environmental control or anti-establishmentarianism. But even they, I think, would agree that the profession has come a long way in acknowledging and accepting a measure of social responsibility.

2. In Arnold's day there was little or no pressure from young lawyers, emerging from law schools, for firms which employed them to undertake non-remunerative, controversial cases. On the contrary, the cycle of the generations was such that most of the younger men in the 40 's and 50's were dominated by economic motivation. They were apt to be followers rather than leaders in professionally and personally dangerous undertakings in the public arena.

The reverse is true today. Many young lawyers are seeking positions in Neighborhood Legal Services, Public Defender's Offices, and the like.

9. See Cornetr, The Trial of Ezra Pound 123 ff. and passim (1966). 
An economic incentive is no longer the focus of their careers. Many more, whose devotion to public service, and whose repudiation of economic ambition, does not extend quite so far, are seeking to combine affluence and employment security with the satisfaction of good works, as they view them, and of exerting pressure upon their law firms to engage in such activities.

3. There was reason, in Arnold's time, for lawyers to fear that clients and prospective clients would disapprove of these unpopular activities, and that their disapproval would defeat the basic reason for the existence of the law firm: that is, to make a living.

Today, a law firm's work on behalf of blacks and civil rights may be hazardous in parts of the country where racial feeling is intense. But the Nation and its business and financial leaders, too, have come a long way. Nothing exists comparable in scope to the practically universal paranoia about Communism which made the defense of civil liberties dangerous for lawyers in Arnold's time.

4. The non-remunerative work undertaken by Arnold's firm was conventionally professional. It was largely litigation in the courts or before administrative officials. The issues were legal, involving questions of constitutional and administrative law and procedure. It is true that many of the problems and principles were novel, and that often the lawyer was compelled to frame tactics, to thrust and counter-attack, with an eye to the impact of public opinion and the press upon his cause. But this is not unfamiliar even to the lawyer engaged in dramatic commercial contests, sensitive as he may be to the canons of propriety. And it is also true that there was constant awareness of the largeness of the issues, the dimensions of the public and human values, that were implicit in the particular case.

Today, much of the non-commercial work comparable in social relevance to that of Arnold's firm is also conventionally professional, but some of it differs in ways that are professionally significant. Law firms are challenged by young lawyers to take on causes rather than cases; and while most civil rights cases are also causes, there is a difference. As the young lawyer views many of today's battles, the client is of relatively little importance. The cause, not the client, is the object of dedication. The client is a technical necessity, not a person whose life or welfare is at stake. The undertaking is shaped and prosecuted not in defense or vindication of the client, but in maximum furtherance of the idea or program. It is, in essence, project-lawyering, rather than client representation. Urban renewal, environment improvement, restructuring of the welfare system, justice for classes of people like the 
American Indians or the Mexican-Americans, and similar great causes, are the focus of the legal work in these cases, rather than the defense or vindication of an individual who has come to the law firm seeking help.

5. In Arnold's time, there was no uncertainty as to the function and responsibility of a law firm. It was to serve and represent each client as an individual, whether the client was a corporate malefactor or a presumably saintly civil libertarian. Once a client had been accepted, the lawyer's course was clear. If the interest of the client required the lawyer to advocate a position or seek a result which he personally dislilied or even which he considered contrary to society's welfare, it was the lawyer's duty to do so with all his mind and heart, subject only to the restrictions and proprieties which the rules and conventions impose. Ezra Pound, the Grand Kleagle of the Ku Klux Klan, a cigarette company, a rapist, a great corporation which polluted the streams, a government typist-all were entitled to and received the same total commitment and dedication, once their cause had been undertaken. And the social implications of the position to be taken on the client's behalf were submerged by the lawyer's dedication to the value of the legal and constitutional system as he saw it, to the duty of the advocate, and to the obligations of advocacy in an adversary system.

Nor was the client permitted to dictate or determine the strategy or substance of the representation, even if the client insisted that his prescription for the litigation was necessary to serve the larger cause to which he was committed. I recall a civil liberties case which the firm undertook and later, with court permission, abandoned because the client insisted upon tactics and positions which we believed were neither appropriate nor permissible in view of the pending judicial proceeding.

Currently, among young lawyers, there is a great deal of ferment about the appropriate role of lawyers and law firms. Young lawyers have raised questions like these: May their law firm, in good conscience, represent a cigarette company, or a manufacturer of napalm or a company that has made defective school buses? Some of these young lawyers are apt to approve of their firm's decision to represent a rapist or someone accused of stealing welfare checks; but to disapprove of its representation of a corporation which has engaged in the production of goods which the lawyers consider to be contrary to the public interest.

Faced with this deeply-felt, passionate attitude of some of the young lawyers of this generation, Arnold's reaction was one of sharp, although amused, disagreement. He was not persuaded that it is commendable for a lawyer to devote his skill to defending a rapist, but disreputable 
to represent a tobacco company. He would have been gaily tolerant of a young man's fancy if he preferred rape to cigarettes. Chacun $\dot{a}$ son gout, he might have said in his World War I French; but he would have laughingly suggested that it is at least debatable whether the defense of the Boston Strangler reflects dedication to a higher social objective than the representation of Philip Morris.

His essential position was that the distinction is irrelevant to the lawyer's mission: Both the rapist and the manufacturer are entitled to counsel and to the lawyer's dedication and zeal in their interests; the social values of their character and conduct are not the lawyer's concern unless they are so abhorrent to the lawyer, and he is so emotionally involved, that he feels that he cannot represent the client with full dedication. There is nothing dishonorable in representing a commercial client for money or in representing a rapist out of a sense of duty to the law and our legal system; and while Arnold felt, as I do, that a law firm's work should include a quantity of social-service, non-remunerative activities, it does not follow that the firm is obliged to assess the social implications of the activities of those seeking its services.

Every person, poor or rich, criminal or corporation, is entitled to the services of a lawyer. This is the fundamental basis of our constitutional system. If a lawyer doesn't choose to represent a particular corporation, he need not do so. The corporation usually can find lawyers; but the lawyer who chooses not to represent a corporation should not elevate his personal predilection into a principle of universal application to others. He should not-he may not-ignore the basic principle of our system that the corporation, whatever the issue may be, is entitled to counsel.

Currently, also, there is a view among some lawyers who are active in the controversies of our time, that a lawyer must or may continue in a case despite the client's deliberate disruption of court proceedings, or that the larwyer may even encourage or participate in his client's efforts to incite public opposition to the trial or to use the legal process, including the courtroom, for violent and disruptive propaganda in support of his social cause. Classical anarchists called this sort of violent, disruptive behavior, attacking an essential instrument of society, the "propaganda of the deed." Earl Browder, former head of the Communist Party, referred to it as using the trial or the hearing room as a "transmission belt" for attacks upon the social order. But to a lawyer, in his role as such, this is and must be entirely unacceptable. The gap between Arnold's generation and the present cannot excuse such a 
departure from the obligations of the profession to protect the legal process and the institutions of the law from efforts to prevent their functioning.

III.

The combination of commercial and socially significant issues handled by Arnold's law firm was uniquely fashioned to his taste. He loved its variety. He immensely enjoyed the profusion of happenings which the assortment of problems brought within the range of his voracious appetite for life and the law. He delighted in the varied and complex life-situations that were laid before the firm, as a sculptor rejoices in his tools and in the clay and marble upon which they operate. But he was not merely an irrepressible and astonishing artist of the law. He was personally involved, personally committed. He had a capacity for indignation whenever he saw unfairness or oppression. He was an individualist, and he was outraged when big government or a big corporation used its power to oppress or circumscribe individuals. I think that, despite his scintillating, devastating writings on the economic and social implications of antitrust, Arnold's passion as an antitruster stemmed directly from this basic, humanistic attitude-a Westerner's dislike of suppression, a Westerner's commitment to the openness of life.

He was one of the last of freedom's gladiators who fought freedom's battles on these terms, the old-fashioned American terms. He was one of the last of the generation which was whole-heartedly committed to the fight for individual freedom, without regard to freedom-for-what: for freedom in the forum, on the street corner, in the market-place; for the freedom of everybody: right, left or just mixed-up-rich man, poor man, beggar man, thief; black man, white man, Ku Kluxer, fascist or Communist.

IV.

That was the shape, in those days, of a commercial law practice which included participation in the great public issues of the time. It demonstrated the conventional characteristics of the lawyer: zealous dedication to the client's cause, insistence upon excellence of product, and the trained and deliberate schizophrenia which is essential to ob. jectivity of substantive advice and procedural strategy: the disciplined isolation of personal passion from judgment which is an essential in. gredient of the professional. 
We are now living in an age which is markedly different from the 40's and 50's. The years between Arnold's law practice and the present are few; but the differences are vast. History in our time has accelerated at a bewildering rate. The crucial drama enacted in the theatre of the law is not the same today. Events have changed the plots, the story lines, the music and even the types of characters.

The terms and conditions of living together in this Nation have rapidly and profoundly changed. The cozy pattern of an Establishment at the top, staffed by wise, dignified, able gentlemen; of a docile generation of young people, caps in hand, waiting their turn to occupy the slots in the Establishment; and of a vast mass of $23,000,000$ blacks at the bottom, humbly accepting crumbs from the table, and ready to serve-this pattern is gone forever. The New Deal ruffled its surface; World War II punched holes in it; the protest movement of the blacks tore it; Vietnam fragmented it; affluence and state assumption of cradleto-grave responsibility undermined the need for it; and the Supreme Court, the Kennedys, President Johnson and the student activists com. pleted the job.-The old pattern is gone.

Because of our constitutional system, our common-law inspiration, and the historic role of lawyers in our Nation's hierarchy, our law and law courts have often been the theatre in which social conflict is acted out and its issues resolved. With the advent of the Warren Court, this unique role was progressively expanded. Procedurally, access to the court for resolution of conflict has been greatly increased by the opening of new doors to adjudication..$^{10}$ That expansion has embraced a new constituency of poor people $e^{11}$ and in greatly increased measure, those convicted of crime. ${ }^{12}$ Substantively, crucial social and political issues that comprehensively affect the structure and dynamics of the Nationranging from controversies as to the duty of the state to provide welfare to indigents ${ }^{13}$ to the composition of elected agencies ${ }^{13}$-have for the first time become grist for the mill of the law, lawyers and courts.

It is not surprising, therefore, that the theatre of the law has undergone radical change. The crucial battleground of the law has shifted; the critical issues have profoundly changed; the initiative has passed

10. See, e.g., Dombrowski v. Pfister, 380 U.S. 479 (1965); Flast v. Cohen, 392 U.S. 83 (1968).

11. See, e.g., Grifin v. Illinois, 351 U.S. 12 (1950); Gidcon v. Wainwright, 372 U.S. 335 (1963).

12. E.g., Mapp v. Ohio, 367 U.S. 643 (1961); Fay v. Noia, 372 U.S. 391 (1963); Peyton v. Rowe, 391 US. 54 (1968); Carafas v. LaVallec, 391 U.S. 234 (1968).

13. Shapiro v. Thompson, 394 U.S. 618 (1969).

14. See, e.g., Baker v. Carr, 369 U.S. 186 (1962). 
from the hands of the Establishment. The fighting theme of the dramas enacted in the theatre of the law is no longer the personal rights of an individual to his personal freedoms, but the social prerogatives of vast numbers of the people.

To the new generation, for example, the defense of Dr. Peters' right to a job, ${ }^{15}$ threatened because he held and expressed modestly deviant political opinions, may seem like a production of Lady Windermere's Fan: it may be interesting and good theatre, it may present a human problem, but it's not significantly "relevant." To them, the crucial unit is not the individual, but masses of people; and the crucial issues relate not to the individual's rights to speak and associate, but to the welfare of multitudes. Only if the individual is attacked because of conduct which is part of a mass activity-only, for example, if the conduct is part of a mass assault upon the Establishment (like the case of the Chicago 7)-is the attack deemed worthy of the indignation of the young. With this democratization of the grievances deemed worthy of passionate commitment, the theatre of the law has radically changed.

Young lawyers have changed. Those who spark their generation are no longer directed by predominantly economic motives. In this respect, they share the temper of their generation. They share its agony and its crusades. They share its demand that they, too, must have a role in shaping the future. In the new theatre of the law, they have seized major roles as script writers, and actors and producers; and the issues in the courts and the techniques of the law show their impact. They have awakened to the promise of an ideal social order that is and has always been implicit in the noble words of the Constitution-in phrases such as equal protection and due process. They have seized the possibility of fulfilling the greatness of our Constitution's words. They have seen that many of the conflicts and injustices of our society may be shaped in the mold of dramas suitable for resolution in the theatre of the law, and that these grievances need not fester and accumulate until violence is the only alternative to endurance.

The result of all of this is not necessarily mournful. America has changed. It will never be the same. Law and the profession and practice of law have changed. They have achieved a new dimension.

Clearly, the time had come for the law to be available-in-fact to all, white, black, rich or poor. Clearly, the time had come for lawyers to be available-in-fact to all. And clearly, I believe, the time had come for the magical phrases of equal protection and due process to acquire a

15. Peters v. Hobby, 349 U.S. 331 (1954). 
new and additional dimension. Clearly, the law's obligation to serve the cause of freedom can no longer be limited to the religious and political guaranties of the First Amendment-to be circumscribed by the stuff of the mind and the eyes and the tongue.

As in any vast, radical move of a society, the changes that are in process have their dangers, their extremes and their absurdities. Law, lawyers and the courts, in our society, in this time of fundamental change, have a profound and challenging role. It is not easy to measure up to the task and the opportunity. Skill, intelligence and the craftsmanship of great architecture are essential. We can overload our legal system. We can overestimate the capability of lawyers in their role as courtroom advocates and of the courts to effect change. The capability of the courts and court-made law, after all, is limited, not only by their nature and their charter but also by the limitations of their techniques. Courts can and must rule "Thou shalt" or "Thou shalt not;" but it is a delusion of competence to assume that they can comprehensively write the detailed prescriptions for a new society. They can administer punishment and distribute absolution, but they are not good or suitable substitutes for legislative and administrative implementation of com. mands. They can rule, for example, that it is the duty of the state to respond to the demands of those who face hunger and malnutrition; but they can hardly be depended upon to decree the amount and type of protein that must be furnished to avoid mental retardation.

The Nation has fortunately come a long way since Justice Jackson's statement in 1941 that "The mere state of being without funds is a neutral fact-constitutionally an irrelevance ...."10 In some instances, a response to poverty may now be a constitutional imperative-not an irrelevance. This was the revolutionary teaching of Griffin v. Illinois, ${ }^{17}$ where, as the dissenting Mr. Justice Harlan protested, the Court held that there are circumstances in which the state has an affirmative duty "to lift the handicaps flowing from different economic circumstances."18

The animating principle of Griffin is an inspiring doctrine with which I agree; but we must be careful and skillful, as well as bold and determined, as we exploit the capability of our Constitution as a self-executing mandate and of our courts to move us with dispatch and effectiveness towards a more just society. We must not disregard their

16. Edwards v. California, 314 U.S. 160, 184-185 (1941) (concurring opinion).

17. 351 U.S. 12 (1956).

18. 351 U.S. at 34. The dissenting opinion of four Justices complained that, "The Constitution requires the equal protection of the law, but it does not require the States to provide equal financial means for all defendants to avail themselves of such laws." Id. at 29. 
limitations; nor may we properly forget that legislatures, Presidents, Governors and mayors, too, have their function or that those who wish to propel our society towards a greater destiny must insist that these agencies of government, like the courts, do their part.

Danger may lie ahead, too, if lawyers, in their role as such, repudiate their professional techniques and responsibilities. As lawyers, they are agents, not principals; and they are agents confined by the rules of their forum. They are obligated to make the legal system work. They are not at liberty, in their capacity as lawyers, to disrupt or participate in disrupting its workings by the tactics of the street or the barroom. Aggressive, powerful representation neither requires nor permits this.

Lawyers are agents, not principals; and they should neither criticize nor tolerate criticism based upon the character of the client whom they represent or the cause that they prosecute or defend. They cannot and should not accept responsibility for the client's practices. Rapists, murderers, child-abusers, General Motors, Dow Chemical-and even cigarette manufacturers and stream-polluters-are entitled to a lawyer; and any lawyer who undertakes their representation must be immune from criticism for so doing.

None of this is in derogation of the massive role of lawyers in shaping America's destiny in the years that lie ahead. Lawyers have a unique capacity to cause all agencies of government, not merely the courts, to meet their responsibilities. And as an officer, not merely of the court but also of the law, the lawyer has a special responsibility in his role as a citizen, to participate in shaping the Nation's policy and program. But in his special, professional capacity, he must act professionally, within the limits and strictures of his calling.

V.

In his last years, Thurman Arnold was sensitively aware of the vast changes which had come about in the law and the objects and conditions of its deployment. He was ever young in spirit, but with his customary candor, he recognized the passage of time. In a speech made on January 24, 1968, almost two years before he died, he said

I am an old man, and most of the things that I remember best never really happened. ${ }^{19}$ 
He saw in the changes much promise as well as considerable peril. Sometimes he seemed to feel that in the theatre of the law the oldfashioned morality play had been displaced by Hair. But he sensed the prospect of the emergence of a new and better order. He had the teacher's perceptiveness about young lawyers, and he saw the solid core of the good that underlay the dust and confusion of their sometimes frantic efforts to get-with-it-not to be left behind in the revolution of their times, but to participate, fully and vividly, in its anguish and effort.

He had little patience with pretentiousness, including the pretensions of judges and lawyers to remake the world. He did not like Latin maxims; he objected to the use of middle initials, including his orm; and he loved to laugh at hyperbole, at pretentious simile and symbol. $\mathrm{He}$ disliked the man-lawyer or layman-who, like the barnyard rooster, believes that it is his crowing that makes the sun rise every morning.

I believe he was enchanted by the happenings in the theatre of the law. I think he was secretly delighted by the vitality reflected in the new activism of young lawyers and the new dimension of the theatre of the law. But he admonished this generation of young lawyers to remember that they are lawyers; that the law is a marvelous and powerful instrument, but that, if it is to be effective, it must be deployed with resourceful use of its own techniques, within the limits of its charter and its capabilities. He would, I think, have wanted young lawyers to enlist in the welfare of their time, but when they did so as lawyers, for others, to act as agents for principals. He would have urged them in this capacity to represent clients, not themselves or their causes; and to do this fiercely, competently and courageously; and to participate as lawyers in all of the causes within the reach of the law and its remedies. He would have wanted them to deploy the law in the interests of people, and he would have himself enlisted his vast ingenuity and resourcefulness in the cause.

To a considerable extent, the vast social decisions of the past decade may be traced to litigation lawyers who had the ingenuity and the skill to shape the issues and to carry them through the maze of the courts, sensitively and astutely. In substantial measure, it was the Warren Court that opened the new frontier of life in this Nation; but the decisions handed down by the Warren Court would never have existed except that lawyers shaped the issues and brought the cases to it. It was lawyers who pointed the way and who made possible 
the advances toward the goal of comprehensive dignity which our Constitution embodies. It was lawyers, engaged in the great and evernew practice of law. It was they who saw the conflicts in justiciable terms; who framed the issues, marshalled the facts and the concepts of the law; and who shaped and guided the cases to the point of decision.

Even in this moment of bitter counter-action in the Nation, the summons, the possibility and the imperative remain to challenge the legal profession: to use the practice of the law comprehensively, in the fashion which our institutions require and make possible; to serve clients in the mundane activities of commerce, but also to enlist in fulfillment of the pledge of our Constitution and laws, in the interests of humanity. 